уДК $655.3 .066(075.8)$

\title{
КОМПЛЕКСНА ОЦІНКА ПОКАЗНИКІВ ЗНОШУВАННЯ БАНКНОТ УКРАЇНСЬКОЇ ГРИВНІ В УМОВАХ РЕАЛЬНОГО ОБІГУ
}

( Т. Ю. Киричок, к.т.н., доцент, НТУУ «КПІ», П. П. Когут, Фабрика банкнотного паперу БМД НБУ, Київ, Україна

Исследования банкнот, находившихся в условиях реального обращения, является основой для выводов о износостойкости банкнот в целом, распределения банкнот по качеству в наличной массе, а также корреляции между режимами обработки банкнот в имитаторах износа и реальным состоянием банкнот в соответствующий период. Для организации исследований износа банкнот крайне важным является установление методов оценки износа с наилучшими показателями точности. Было исследовано выборки банкнот 1 грн и 2 грн из хранилища Национального банка Украины. Размер каждой выборки составил 1010 шт. в соответствии с методом отбора - методом комбинированного многоступенчатого отбора, который сочетает стратифицированный (районированный) отбор и на последнем этапе, бесповторный случайный отбор. Каждая выборка была рассортирована на десять групп согласно степени износа. Было исследовано тринадцать показателей износа (яркость, пористость, шероховатость, нулевая разрывная длина, жесткость (разными методами), устойчивость кромки до надрыва и т.д.) для групп банкнот наилучшего качества (New) и наиболее изношенных (Absolutely unfit). Были определены показатели точности для всех показателей износа. Предложено установить рейтинг показателей износа, используя совместную оценку, учитывающую изменение показателя в результате износа, относительную погрешность для новых банкнот и относительную погрешность для изношенных банкнот. Наивысшую оценку получили такие показатели износа как шероховатость (по Бендстену) и жесткость (методом резонанса).

Research of banknotes, which were in a real use conditions, are the basis for conclusions regarding the durability of banknotes in general, the distribution of the quality of banknotes in the money supply, as well as the correlation between modes of processing of banknotes in simulators and the actual state of wear of banknotes in the period. For organizing research of notes deterioration it is very important to identify the deterioration measurement methods which demonstrate the highest accuracy indices. The sam-

ples of taken from central bank stock 1 hryvnia and 2 hryvnia notes have been studied. The size of each sample was 1010 ps. in accordance with sampling method of combination of multistage sampling, which will combine stratified (homologated) selection, 
and nonrepeating random selection at the last stage. Each sample was sorted to ten groups of quality from the point of view of deterioration. The groups of best quality ( $\mathrm{New}$ ) and the worst quality (Absolutely unfit) were examined by measuring of thirteen deterioration characteristics such as brightness, porosity, surface roughness, zero-span breaking strength, edge tearing resistance, stiffness (different methods) etc. The different accuracy indices for each deterioration characteristics were established. It was proposed to range deterioration characteristics using simultaneous estimation by taking into account the variation of characteristics during deterioration, relative error for new banknote and relative error for absolutely unfit banknote. The best rated methods are surface roughness (Bendsten method) and stiffness (resonance method).

\section{Постановка проблеми}

Банкноти належать до поліграфічної продукції, що перебуває в умовах інтенсивного використання, під час якого на банкноти діє низка факторів, що тою чи іншою мірою спричиняють зношування. Підвищення зносостійкості банкнот $є$ завданням державного значення. Дослідження банкнот, що перебували в умовах реального обігу, $\epsilon$ основою для висновків щодо зносостійкості банкнот в цілому, розподілу банкнот за якістю в готівковій масі, а також кореляції між режимами обробки банкнот в імітаторах зношування та реальним станом банкнот у відповідний період. Для організації досліджень зношування банкнот вкрай важливим $€$ встановлення науково обґрунтованої вибірки досліджуваних банкнот, а також вибір показників зношування, котрі дозволяють оцінити зношування 3 найвищою точністю.

\section{Аналіз попередніх досліджень}

Під час приймання, видачі, оброблення готівки контролюють низку ознак зношування та по- шкодження [1]: захисні ознаки, видимі в інфрачервоному, ультрафіолетовому діапазоні, захисні ознаки з магнітними властивостями, а також, за наявності технічних можливостей, інші захисні ознаки; механічні пошкодження (надриви, отвори, відсутність кутів та частин, зім'ятість); загальне зношування; локальне та загальне забруднення.

В наукових дослідженнях процесів зношування банкнот окрім наведених вище ознак зношування та пошкодження також досліджують зміни пористості та шорсткості паперу, його міцністних характеристик. Оскільки загальне забруднення $€$ основною причиною вилучення банкнот з обігу, тому методам його контролю приділяється велика увага. Тут до ознак, що контролюють, належить зміна оптичних характеристик банкнот зміна колірності, що контролюється візуально персоналом, зміна оптичної щільності [2], вимірювання видимого світла, відображеного від банкноти [3], спектральні характеристики банкнот в діапазоні 380-740 нм та пропускання ІЧ-випромінювання [3, 4]. 
Під час досліджень банкноти розподіляють на декілька груп за якістю. Зазвичай таких груп п'ять [3]: 1 клас - Superfit (абсолютно відповідні - як нові), 2 клас - Fit (відповідні), 3 клас - Acceptable (прийнятні), 4 клас - Unfit (невідповідні), 5 клас - Super unfit (абсолютно невідповідні). Віднесення банкноти до перших чотирьох груп якості дозволяють визначити доцільність її перебування в обігу. Під час наукових досліджень розподіл, зазвичай, здійснюється вручну.

Щодо отримання вибірки зношених банкнот, то досліджують вибірки банкнот, що перебували в умовах реального обігу [3], або здійснюють імітацію обігу [4]. При цьому в останньому випадку застосовують так звані імітатори обігу - прилади, що 3 певним ступенем достовірності імітують механічні та хімічні впливи на банкноти [5], або імітацію зношування із залученням персоналу, котрий з певною періодичністю здійснює контакт з тестовими банкнотами [6]. Всі реалізовані підходи до отримання вибірки зношених банкнот мають певні недоліки. Так, в дослідженнях з використанням імітаторів зношування [5] постає питання кореляції результатів, отриманих в імітаторах та в реальних умовах обігу, котре досі, фактично, не вирішено [3] через складність вибору режимів обробки банкнот в імітаторі (тривалості, кількості обертів за хвилину, температури, складу забруднювальної суміші тощо [3]). Те саме зауваження можна віднести й до імітації зношування із залучен- ням персоналу [6]. В такому дослідженні частково враховано, що фактором найбільшого впливу на банкноти $€$ люди, оскільки, основним чинником забруднення банкнот $€$ дотики пальців, що залишають відбитки, котрі з часом накопичуються та утворюють жовто-коричневий шар застарілого шкірного сала $[3,7]$. Але в умовах реального обігу банкноти контактують $з$ набагато більшим спектром людей, ніж банківські працівники, залучені до дослідження [6]. Тому питання кореляції імітації та реальних умов обігу при такому підході знімається не повністю.

Таким чином, тільки вивчення змін показників якості банкнот, що перебували в умовах реального обігу, дає достовірні результати для висновків щодо зносостійкості банкнот в цілому, розподілу банкнот за якістю в готівковій масі, а також кореляції між режимами обробки банкнот в імітаторах зношування та реальним станом банкнот у відповідний період. Для організації досліджень зношування банкнот вкрай важливим є встановлення науково обґрунтованої вибірки досліджуваних банкнот.

\section{Результати проведених досліджень}

Для здійснення вибіркового дослідження, яке б дозволило 3 високим рівнем ймовірності забезпечити науково обґрунтовані результати, доцільно використовувати метод комбінованого багатощаблевого відбору, який поєднуватиме стратифікований (районований) відбір та, на останньому етапі відбору, безповторний випадковий відбір. При 
безповторному випадковому відборі кожна раніше відібрана одиниця не повертається в генеральну сукупність і в подальшій вибірці участі не бере.

Відзначимо, що вибірка вважається статистично репрезентативною тоді, коли випадкові помилки $є$ незначними. Точність одержаних результатів прямо пропорційна залежності від обсягу сформованої вибіркової сукупності: збільшується обсяг вибірки - підвищується точність.

За даними Національного банку України, станом на 01.07.2012 в готівковому обігу країни знаходилося близько 2,6 млрд банкнот на загальну суму 216,8 млрд грн [8]. 3 метою організації першого етапу відбору, необхідно обрати критерій районування (стратифікування), за який в нашому випадку ми обираємо номінал грошових банкнот. В результаті проведення такої процедури ми отримуємо 9 класів множин (банкноти номіналом 1, 2, 5, 10, 20, 50, 100, 200, 500 гривень). Уводити такий критерій районування як рік випуску банкноти, з одного боку, є важливим і необхідним, а 3 іншого - таким, що може суттєво вплинути на складність організації дослідження, особливо, якщо врахувати, що облік банкнот за номіналами, відповідно до нормативно-правових актів НБУ провадиться за критеріями «Банкноти зразків до 2003 року» та «Банкноти зразка 2003 та наступних років випуску» [8]. Крім того, не видається можливим враховувати регіональну чи вікову специфіку грошової культури населення (різні стилі використання банкнот як засобу заощадження та як засобу розрахунку). Тому, в разі прийняття в якості генеральної сукупності тих банкнот, які надходять до сховища НБУ (або будь-якого банку) будемо вважати, що регіональні та вікові особливості грошової культури не є значущими, адже до сховища такого типу потрапляють різні банкноти 3 приблизно однаковою ймовірністю, незалежно від того, перебували в обігу в якості платіжного засобу чи зберігалися у формі заощаджень.

На наступному етапі використаємо метод випадкового безповторного відбору, оскільки він охоплює постійно нові одиниці сукупності, а повторний - одну і ту ж сукупність, тому безповторний відбір дає більш точні результати. Безповторний випадковий відбір буде реалізовуватися у кожному класі вказаних вище множин. Для розрахунку обсягу вибіркової сукупності банкнот, на основі яких буде здійснене оцінювання ступеня зношуваності, використаємо наступну формулу:

$$
n=\frac{n^{2} \sigma^{2} N}{\Delta^{2} N+t^{2} \sigma^{2}}
$$

де $\mathrm{n}$ - обсяг вибіркової сукупності, N - обсяг генеральної сукупності, $\sigma^{2}-$ дисперсія ознаки в генеральній сукупності, $\Delta-$ гранична похибка вибірки, тобто максимально можлива похибка для прийнятої ймовірності $\mathrm{P}$, а $\mathrm{t}$ - коефіцієнт довіри. На практиці найчастіше використовують ймовірність 0,95 та 0,954 (відповідні їм величини $\mathrm{t}$ становлять 1,96 та 2,00). 
Отже достатній обсяг вибірки залежить від ступеня однорідності генеральної сукупності $\left(\sigma^{2}\right)$, ймовірності, $з$ якою гарантується результат (t) i необхідної точності вибіркової оцінки $(\Delta)$.

Звичайно, за генеральну сукупність для кожного класу об'єктів можна приймати всю кількість банкнот певного номіналу, які знаходяться у обігу. Але це не має ніякої доцільності, адже навіть та кількість банкнот, яка надходить до сховищ банку є достатньою, щоб здійснювати статистично обґрунтовані розрахунки вибіркової сукупності. Припустимо, що у нашому розпорядженні $\epsilon$ не менше, ніж 10000 банкнот кожного номіналу.

В табл. 1 наведено розрахунок вибіркових сукупностей за умови, що генеральна сукупність складає по 11111 (число взято навмання) банкнот кожного номіналу (тобто >10000, що дає змогу говорити про відповідність вимогам закону великих чисел).

Звичайно, щоб отримати більш точні результати, варто використовувати вибірки більшого обсягу і, відповідно, 3 меншою похибкою. У нашому випадку з усіх вищенаведених, найбільш точно закон розподілу ознаки в генеральній сукупності буде відтворюватися у вибірковій сукупності з обсягом 2040 банкнот (довірча ймовірність - 99 \% і похибка $3 \%$ ), однак з метою зменшення трудомісткості вирішено встановити довірчу ймовірність на рівні 95,4 \% і вибірку банкнот кожного номіналу на рівні 1010 шт.

Отже, з метою визначення показників якості банкнот, призначених до вилучення з обігу та знищення, проведені випробування вибірок отриманих з Центрального сховища Національного банку банкнот низьких номіналів (1 та 2 грн) обсягом 1010 шт. кожного номіналу. Такий вибір обумовлений тим, що саме вказані номінали зазнають найбільших фізико-механічних навантажень у процесі обігу. Крім того, банкноти номіналу 1 грн. у процесі виготовлення не проходять стадії друку інтагліо, а усі банкноти починаючи 3 номіналу 2 грн проходять цю стадію друкування, під час якого піддаються тисненню із надзвичайно великими зусиллями, що

Таблиця 1

Розрахунок вибіркових сукупностей

\begin{tabular}{|c|c|c|}
\hline $\begin{array}{c}\text { Гранична теоретична } \\
\text { похибка } \Delta, \%\end{array}$ & Довірча ймовірність & $\begin{array}{c}\text { Вибірка для банкнот кожного } \\
\text { номіналу, шт. }\end{array}$ \\
\hline \multirow{2}{*}{$5 \%$} & $99 \%$ & 832 \\
\cline { 2 - 3 } & $95,4 \%$ & 386 \\
\hline \multirow{2}{*}{$4 \%$} & $99 \%$ & 1248 \\
\cline { 2 - 3 } & $95,4 \%$ & 591 \\
\hline \multirow{2}{*}{$3 \%$} & $99 \%$ & 2040 \\
\cline { 2 - 3 } & $95,4 \%$ & 1010 \\
\hline
\end{tabular}


може спричинити зміни у структурі паперової основи.

Сортування з метою виявлення зношених банкнот провадиться як апаратним способом (з використанням спеціалізованого обладнання $[9,10])$, так i візуально, а також комбінацією цих способів.

Під час досліджень банкноти розподілено на десять груп за якістю - від найменш пошкоджених до найбільш. Розподіл здійснено вручну експертом готівкового обігу. Порівняно з [3] розширено градацію класів банкнот: 1 клас - New (нові), 2 клас - Superfit (абсолютно відповідні - як нові), 3 клас - Fit (відповідні), 4 клас - Semifit (майже відповідні), 5 клас Super acceptable (цілком прийнятні), 6 клас - Acceptable (прийнятні), 7 клас Semiacceptable (майже прийнятні), 8 клас - Unfit (невідповідні), 9 клас - Super unfit (дуже невідповідні), 10 клас - Absolutely unfit (абсолютно невідповідні).

у подальшому досліджено характеристики останньої за якістю групи (100 найбільш зношених та пошкоджених банкнот - 10 клас - Absolutely unfit (абсолютно невідповідні)) та групи 3 найкращою якістю (100 банкнот якості 1 клас - New (нові)).

В наших дослідженнях встановлено зміни в результаті зношування таких показників: яскравість [11, 12], повітропроникність [13], шорсткість (за Бендстеном) [14], опір зламу (кількість подвійних перегинів) [15], руйнівне зусилля [16, 17], показник відносного подовжен- ня [18], стійкість крайки до надриву [19], стійкість крайки до надриву роздиранням [19], нульова розривна довжина [20, 21], жорсткість за Табером [22], жорсткість за методом резонансу [23], жорсткість за методом кільця [24, 25], зміна маси банкHOT.

Спостерігалося суттєве зменшення яскравості банкнот як з лицьового, так і зі зворотного боку. Зміна яскравості помітно менша у банкнот 2 грн (на 20,6\%, в той час як у 1 грн $30,2 \%)$, що, припустимо, $€$ наслідком застосування інтагліодруку для цих банкнот.

У результаті зношування внаслідок розпушування структури паперу відбувається збільшення повітропроникності (на 78,8 \%). Дуже значно - на $988,8 \%$ у 1 грн та на 277,6 у 2 грн банкнот зростає шорсткість, що викликано як розпушуванням структури, так i виходом окремих волокон 3 товщі паперу внаслідок зношування. Різницю у збільшенні шорсткості у 1 грн та у 2 грн також можна пояснити каландрувальним ефектом інтагліодруку.

Суттєво (на 82,9 \% у 1 грн та на $65,3 \%$ у 2 грн знизився опір зламу (кількість подвійних перегинів). Таку ж тенденцію мають й інші показники: зменшилися як у машинному, так і в поперечному напрямі руйнівне зусилля, руйнівне зусилля, показник відносного подовження, стійкість крайки до надриву, стійкість крайки до надриву роздиранням, нульова розривна довжина, жорсткість за Табером, жорсткість за методом резонансу, жорсткість за методом кільця (таблиці 
5-11), причому зміни для банкнот 1 грн більші, ніж для 2 грн. Внаслідок накопичення забруднень на поверхні банкнот збільшилася маса банкноти (на $5,6 \%$ у 1 грн та на 7 \% у 2 грн таблиця 12). Зміна маси - єдиний показник зношування, за яким банкноти з інтагліодруком (2 грн) мають гірший показник, ніж банкноти без нього (1 грн). Причини цього потребують додаткового вивчення.

Необхідно визначити, які 3 показників зношування доцільно застосовувати з точки зору точності вимірювань.

До показників точності можливо віднести зміну показника в результаті зношування $\Delta \mathrm{X}$, середнє квадратичне відхилення $\sigma$, середню похибку середнього арифметичного $\mathrm{m}$, коефіцієнт варіації $v$ та відносну похибку $\delta$ для нових та зношених банкнот. Ці показники, визначені за результатами випробовувань досліджуваних банкнот, наведено в таблицях 2-12. В таблицях середньоквадратичне відхилення обчислено за формулою:

$$
\sigma=\sqrt{\frac{1}{n} \sum_{i=1}^{n}\left(x_{i}-\bar{x}\right)^{2}},
$$

де $\sigma$ - середнє квадратичне відхилення; $\mathrm{n}$ - число спостережень $(\mathrm{n}=1), \overline{\mathrm{x}}$ - середнє арифметичне результатів спостережень $x_{i}(i=1 \div n)$ :

$$
\bar{x}=\frac{1}{n} \sum_{i=1}^{n} x_{i} .
$$

Середню похибку середнього арифметичного (m) розраховували за формулою:

$$
m= \pm \frac{\sigma}{\sqrt{n}}
$$

Коефіцієнт варіації (у \%) дорівнює

$$
v=\frac{\sigma}{\bar{x}} \cdot 100
$$

Відносна похибка за кожним методом вимірювання (у \%):

$$
\delta= \pm \frac{m}{\bar{x}} \cdot 100
$$

Зміна показника (у \%) в результаті зношування визначалася наступним чином:

$$
\Delta X=\left|\frac{\bar{X}_{\text {new }}-\bar{X}_{\text {det }}}{\bar{X}_{\text {new }}}\right| \cdot 100,
$$

де $\bar{X}_{\text {new }}$ - середнє арифметичне результатів спостережень для банкнот 1 класу - New (нові), $\bar{X}_{\text {det }}$ - середнє арифметичне результатів спостережень для зношених банкнот 10 класу - Absolutely unfit (абсолютно невідповідні).

Однак, аналіз формул (2-6) показує, що середнє квадратичне відхилення $\sigma$, середня похибка середнього арифметичного $\mathrm{m}$, коефіцієнт варіації $v$ та відносна похибка $\delta \in$ взаємозалежними. Тому доцільно для встановлення точності ј-го показника зношування враховувати зміну показника в результаті зношування $\Delta \mathrm{X}$, відносну похибку для нових $\delta_{\text {new }}$ та відносну похибку для зношених банкнот $\delta_{\text {det }}$. При цьому бралося до уваги, що відносна похибка враховує як середнє квадратичне відхилення (показник розсіювання ре- 
зультатів спостережень відносно математичного сподівання), так і число спостережень:

$$
\delta= \pm \frac{\sigma}{\bar{x} \cdot \sqrt{n}} \cdot 100
$$

Пропонується визначити сумісну оцінку точності кожного показника зношування таким чином:

$$
\mathrm{X}_{\delta}=\frac{\Delta \mathrm{X}}{\delta_{\text {заг }}}
$$

де $\delta_{\text {заг }}-$ загальна абсолютна похибка:

$$
\delta_{\text {заг }}=\sqrt{\delta_{\text {new }}^{2}+\delta_{\text {det }}^{2}},
$$

де $\delta_{\text {new }}$ - відносна похибка для банкнот 1 класу - New (нові), $\delta_{\text {det }}$ - відносна похибка для зношених банкнот 10 класу Absolutely unfit (абсолютно невідповідні).

Висновок щодо застосування методу вимірювань робитиметься на основі аналізу сумісної оцінки показників зношування банкнот.

В таблиці 13 наведено рейтинг показників зношування 3 точки зору точності. Видно, що найнижчий рівень відносних похибок нових банкнот (менш 0,5 \%) мають яскравість, шорсткість (за Бендстеном), жорсткість за методом резонансу, зміна маси банкнот. Оскільки на банкноти в процесі реального обігу діє низка факторів, що 3 різною ймовірністю спричиняють пошкодження банкнот, то відносні похибки для зношених банкнот (i, відповідно, варіація результатів вимірювань) зростають практично для всіх показників. Розмір відносної похибки зношених банкнот для всіх показників зношування, окрім повітропроникності, не перевищує похибки вибіркової сукупності (3 \%). Рейтинг показників зношування з точки зору точності (від найкращого до найгіршого) 3 урахуванням сумісної оцінки за формулою (8) є таким: шорсткість (за Бендстеном), жорсткість за методом резонансу, жорсткість за методом кільця, жорсткість за Табером, стійкість крайки до надриву роздиранням, руйнівне зусилля, зміна яскравості, опір зламу (кількість подвійних перегинів), повітропроникність, зміна маси банкнот, показник відносного подовження, нульова розривна довжина, стійкість крайки до надриву. Доцільно в подальших дослідженнях встановити оптимальні показники зношування 3 точки зору трудомісткості, можливості оперативного контролю тощо. 
Таблиця 2

Результати статистичної обробки даних зміни яскравості банкнот,

(\%)

\begin{tabular}{|c|c|c|c|c|c|}
\hline & & \multicolumn{4}{|c|}{ Номінал банкноти. грн } \\
\hline & & \multicolumn{2}{|c|}{1} & \multicolumn{2}{|c|}{2} \\
\hline & & Лице & Зворот & Лице & Зворот \\
\hline \multirow{7}{*}{$\begin{array}{l}\overline{0} \\
\text { o } \\
\text { I }\end{array}$} & Середнє $\overline{\mathrm{X}}_{\text {new }}$ & 74,820 & 59,440 & 66,020 & 51,900 \\
\hline & $\begin{array}{l}\text { Середньо-квадра- } \\
\text { тичне відхилення }\end{array}$ & 0,743 & 0,944 & 0,420 & 0,614 \\
\hline & $\begin{array}{c}\text { Середня похибка } \\
\text { середнього } \\
\text { арифметичного } \\
\end{array}$ & 0,074 & 0,094 & 0,042 & 0,061 \\
\hline & Відносна похибка, \% & 0,099 & 0,159 & 0,064 & 0,118 \\
\hline & $\begin{array}{c}\text { Середня відносна } \\
\text { похибка, \% } \\
\end{array}$ & \multicolumn{4}{|c|}{0,110} \\
\hline & Коефіцієнт варіації, \% & 0,993 & 1,588 & 0,636 & 1,183 \\
\hline & $\begin{array}{c}\text { Середній коефіцієнт } \\
\text { варіації, \% } \\
\end{array}$ & \multicolumn{4}{|c|}{1,100} \\
\hline \multirow{9}{*}{ 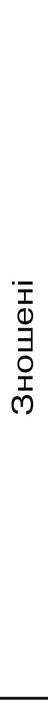 } & Мінімум & 28,830 & 28,950 & 37,960 & 29,230 \\
\hline & Максимум & 62,910 & 66,310 & 62,730 & 50,470 \\
\hline & Середнє $\overline{\mathrm{X}}_{\text {det }}$ & 47,880 & 44,970 & 52,560 & 42,260 \\
\hline & $\begin{array}{l}\text { Середньо-квадра- } \\
\text { тичне відхилення }\end{array}$ & 6,690 & 7,700 & 5,060 & 4,340 \\
\hline & $\begin{array}{c}\text { Середня похибка } \\
\text { середнього } \\
\text { арифметичного } \\
\end{array}$ & 0,669 & 0,770 & 0,506 & 0,434 \\
\hline & Відносна похибка, \% & 1,397 & 1,712 & 0,963 & 1,027 \\
\hline & $\begin{array}{c}\text { Середня відносна } \\
\text { похибка, \% } \\
\end{array}$ & \multicolumn{4}{|c|}{1,275} \\
\hline & Коефіцієнт варіації, \% & 13,970 & 17,120 & 9,630 & 10,270 \\
\hline & $\begin{array}{c}\text { Середній коефіцієнт } \\
\text { варіації, \% } \\
\end{array}$ & \multicolumn{4}{|c|}{12,748} \\
\hline & $\begin{array}{c}\text { Зміна показника в ре- } \\
\text { зультаті зношування, \% }\end{array}$ & 36,006 & 24,344 & 20,388 & 18,574 \\
\hline & $\begin{array}{c}\text { Середня зміна } \\
\text { показника в результаті } \\
\text { зношування, \% }\end{array}$ & \multicolumn{4}{|c|}{24,828} \\
\hline & Сумісна оцінка & 25,705 & 14,157 & 21,131 & 17,967 \\
\hline & $\begin{array}{c}\text { Середня сумісна } \\
\text { оцінка }\end{array}$ & \multicolumn{4}{|c|}{19,740} \\
\hline
\end{tabular}


Таблиця 3

Результати статистичної обробки даних зміни банкнотами шорсткості та повітропроникності

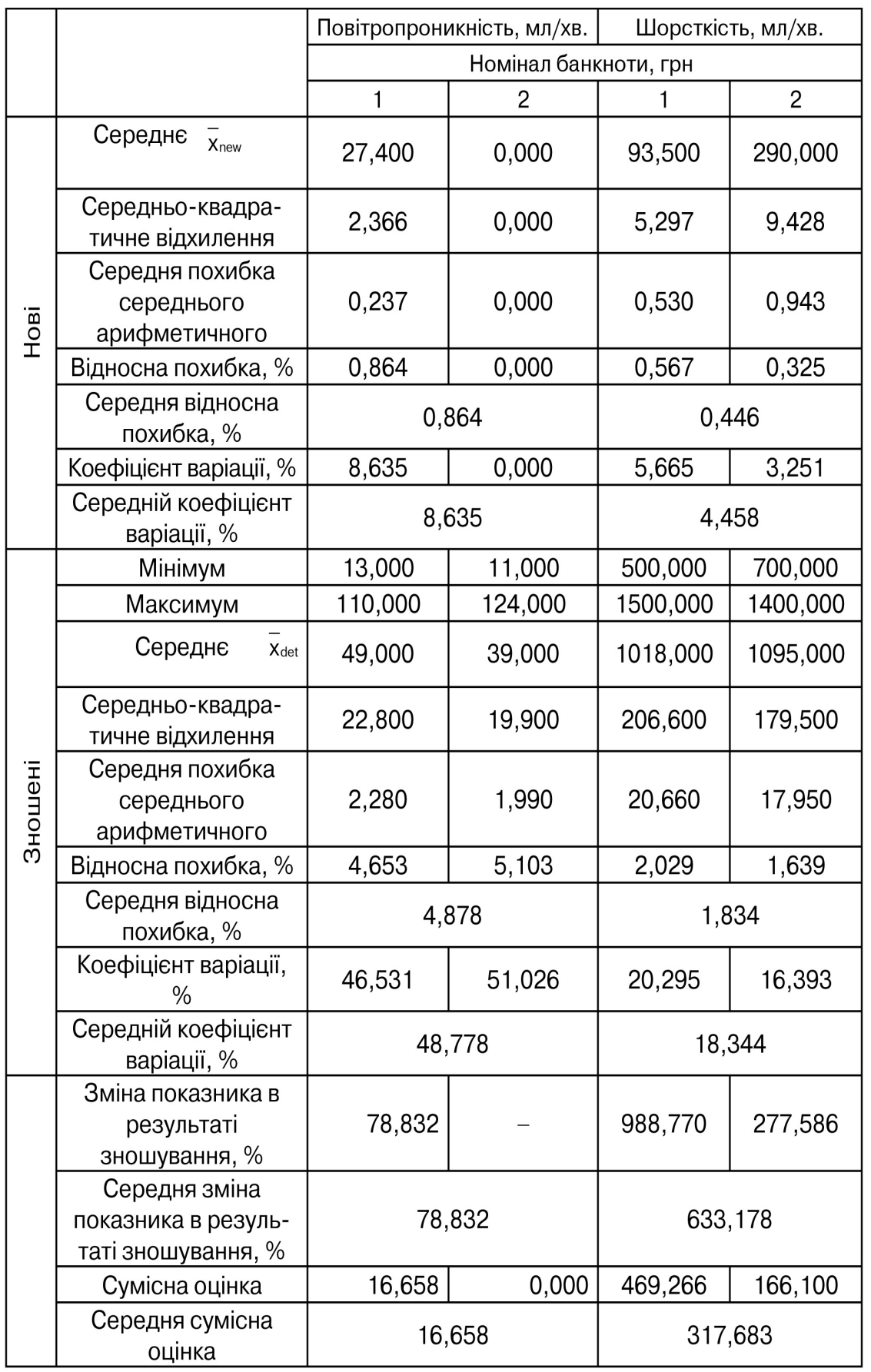


Таблиця 4

Результати статистичної обробки даних зміни банкнотами опору зламу (кількість подвійних перегинів, шт.)

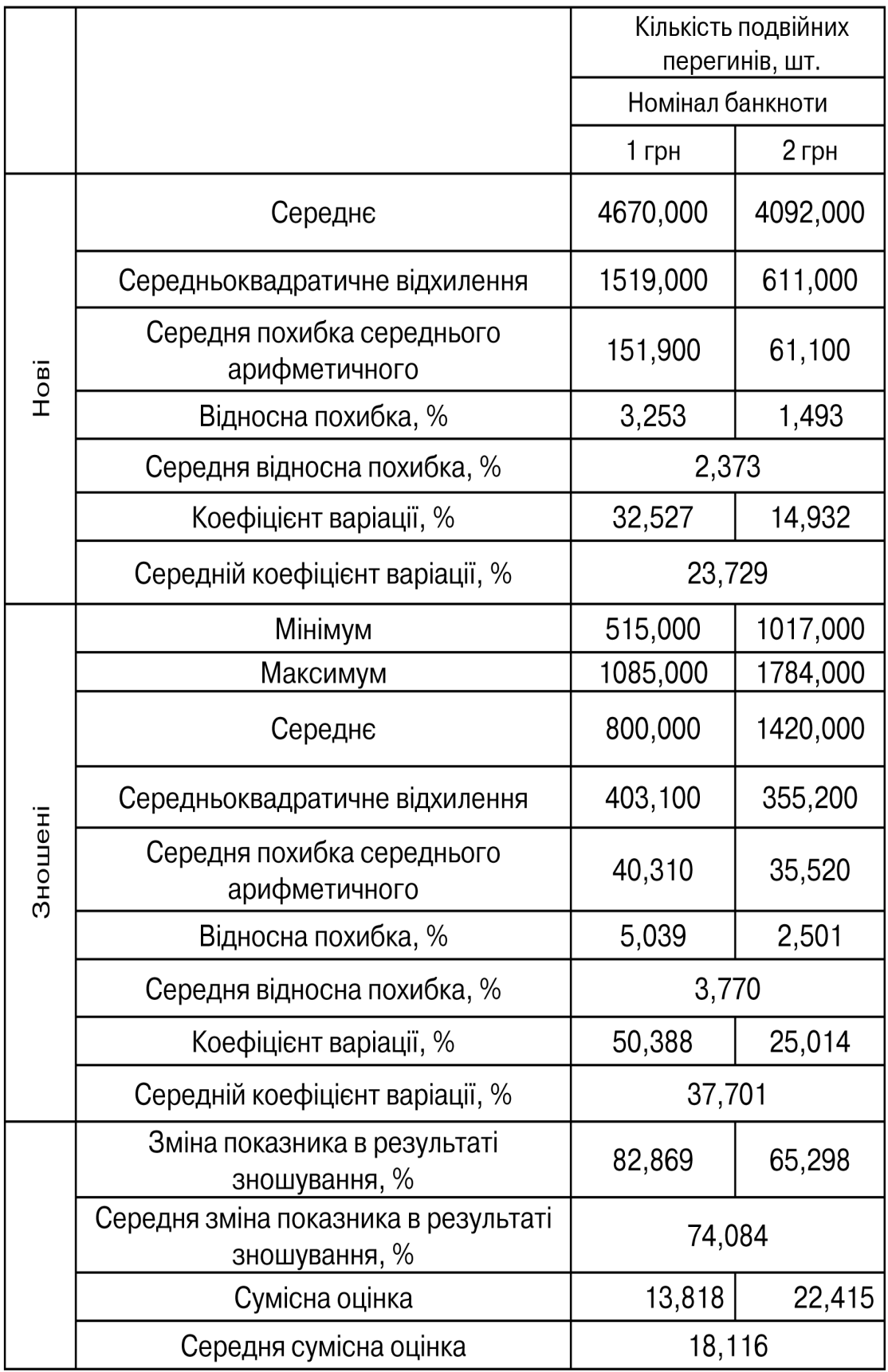


Таблиця 5

Результати статистичної обробки даних зміни банкнотами руйнівного зусилля (H)

\begin{tabular}{|c|c|c|c|c|c|}
\hline & & \multicolumn{4}{|c|}{ Руйнівне зусилля, Н } \\
\hline & & \multicolumn{4}{|c|}{ Номінал банкноти } \\
\hline & & \multicolumn{2}{|c|}{1 грн } & \multicolumn{2}{|c|}{2 грн } \\
\hline & & $\begin{array}{c}\text { Машинний } \\
\text { напрям }\end{array}$ & $\begin{array}{c}\text { Поперечний } \\
\text { напрям }\end{array}$ & $\begin{array}{c}\text { Машинний } \\
\text { напрям }\end{array}$ & $\begin{array}{c}\text { Поперечний } \\
\text { напрям }\end{array}$ \\
\hline \multirow{7}{*}{ 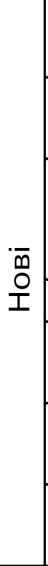 } & Середнє $\bar{x}_{\text {new }}$ & 131,400 & 62,500 & 130,900 & 60,130 \\
\hline & $\begin{array}{l}\text { Середньо-квадра- } \\
\text { тичне відхилення }\end{array}$ & 15,800 & 1,200 & 8,219 & 1,256 \\
\hline & $\begin{array}{c}\text { Середня похиб- } \\
\text { ка середнього } \\
\text { арифметичного }\end{array}$ & 1,580 & 0,120 & 0,822 & 0,126 \\
\hline & Відносна похибка, \% & 1,202 & 0,192 & 0,628 & 0,209 \\
\hline & $\begin{array}{c}\text { Середня віднос- } \\
\text { на похибка, \% }\end{array}$ & \multicolumn{4}{|c|}{0,558} \\
\hline & $\begin{array}{c}\text { Коефіцієнт варіації, } \\
\text { \% }\end{array}$ & 12,024 & 1,920 & 6,279 & 2,089 \\
\hline & $\begin{array}{l}\text { Середній коефі- } \\
\text { цієнт варіації, \% }\end{array}$ & \multicolumn{4}{|c|}{5,578} \\
\hline \multirow{9}{*}{ 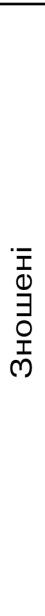 } & Мінімум & 33,8 & 28,7 & 73,1 & 37,5 \\
\hline & Максимум & 101 & 45 & 107,6 & 53,8 \\
\hline & Середнє & 66,4 & 38,1 & 86,7 & 45,4 \\
\hline & $\begin{array}{l}\text { Середньо-квадра- } \\
\text { тичне відхилення }\end{array}$ & 18,9 & 5,02 & 11,5 & 6,28 \\
\hline & $\begin{array}{c}\text { Середня похиб- } \\
\text { ка середнього } \\
\text { арифметичного }\end{array}$ & 1,890 & 0,502 & 1,150 & 0,628 \\
\hline & Відносна похибка, \% & 2,846 & 1,318 & 1,326 & 1,383 \\
\hline & $\begin{array}{c}\text { Середня відносна } \\
\text { похибка, \% }\end{array}$ & \multicolumn{4}{|c|}{1,718} \\
\hline & Коефіцієнт варіації, \% & 28,464 & 13,176 & 13,264 & 13,833 \\
\hline & $\begin{array}{l}\text { Середній коефі- } \\
\text { цієнт варіації, \% }\end{array}$ & \multicolumn{4}{|c|}{17,184} \\
\hline & $\begin{array}{c}\text { Зміна показника в } \\
\text { результаті } \\
\text { зношування, \% } \\
\end{array}$ & 49,467 & 39,040 & 33,766 & 24,497 \\
\hline & $\begin{array}{c}\text { Середня зміна по- } \\
\text { казника в резуль- } \\
\text { таті зношування, \% }\end{array}$ & \multicolumn{4}{|c|}{36,693} \\
\hline & Сумісна оцінка & 16,009 & 29,320 & 23,009 & 17,511 \\
\hline & $\begin{array}{c}\text { Середня сумісна } \\
\text { оцінка }\end{array}$ & \multicolumn{4}{|c|}{21,462} \\
\hline
\end{tabular}




\section{ТЕХНОЛОГІЧН І ПРОЦЕСИ}

\section{Результати статистичної обробки даних зміни банкнотами показника відносного подовження (\%)}

\begin{tabular}{|c|c|c|c|c|c|}
\hline & & \multicolumn{4}{|c|}{ Відносне подовження, \% } \\
\hline & & \multicolumn{4}{|c|}{ Номінал банкноти } \\
\hline & & \multicolumn{2}{|c|}{1 грн } & \multicolumn{2}{|c|}{2 грн } \\
\hline & & $\begin{array}{c}\text { Машинний } \\
\text { напрям }\end{array}$ & $\begin{array}{c}\text { Поперечний } \\
\text { напрям }\end{array}$ & $\begin{array}{c}\text { Машинний } \\
\text { напрям }\end{array}$ & $\begin{array}{c}\text { Поперечний } \\
\text { напрям }\end{array}$ \\
\hline \multirow{7}{*}{$\begin{array}{l}\text { o } \\
\text { ơ } \\
\text { I }\end{array}$} & Середнє & 1,880 & 4,160 & 1,690 & 4,450 \\
\hline & $\begin{array}{c}\text { Середньо-квадра- } \\
\text { тичне відхилення }\end{array}$ & 0,327 & 0,481 & 0,116 & 0,271 \\
\hline & $\begin{array}{c}\text { Середня похибка } \\
\text { середнього } \\
\text { арифметичного } \\
\end{array}$ & 0,033 & 0,048 & 0,012 & 0,027 \\
\hline & Відносна похибка, \% & 1,739 & 1,156 & 0,686 & 0,609 \\
\hline & $\begin{array}{c}\text { Середня відносна } \\
\text { похибка, \% }\end{array}$ & \multicolumn{4}{|c|}{1,048} \\
\hline & $\begin{array}{c}\text { Коефіцієнт варіації, } \\
\text { \% }\end{array}$ & 17,394 & 11,563 & 6,864 & 6,090 \\
\hline & $\begin{array}{c}\text { Середній коефіцієнт } \\
\text { варіації, \% } \\
\end{array}$ & \multicolumn{4}{|c|}{10,477} \\
\hline \multirow{9}{*}{ 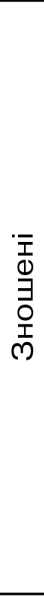 } & Мінімум & 1,2 & 2,9 & 1,2 & 3 \\
\hline & Максимум & 2,4 & 3,7 & 2,4 & 3,7 \\
\hline & Середнє & 1,6 & 3,3 & 1,5 & 3,36 \\
\hline & $\begin{array}{c}\text { Середньо-квадра- } \\
\text { тичне відхилення }\end{array}$ & 0,34 & 0,27 & 0,34 & 0,24 \\
\hline & $\begin{array}{c}\text { Середня похибка } \\
\text { середнього } \\
\text { арифметичного }\end{array}$ & 0,034 & 0,027 & 0,034 & 0,024 \\
\hline & Відносна похибка, \% & 2,125 & 0,818 & 2,267 & 0,714 \\
\hline & $\begin{array}{c}\text { Середня відносна } \\
\text { похибка, \% } \\
\end{array}$ & \multicolumn{4}{|c|}{1,481} \\
\hline & Коефіціент варіації, \% & 21,250 & 8,182 & 22,667 & 7,143 \\
\hline & $\begin{array}{l}\text { Середній коефі- } \\
\text { цієнт варіації, \% }\end{array}$ & \multicolumn{4}{|c|}{14,810} \\
\hline & $\begin{array}{c}\text { Зміна показника в } \\
\text { результаті } \\
\text { зношування, \% } \\
\end{array}$ & 14,894 & 20,673 & 11,243 & 24,494 \\
\hline & $\begin{array}{c}\text { Середня зміна по- } \\
\text { казника в резуль- } \\
\text { таті зношування, \% }\end{array}$ & \multicolumn{4}{|c|}{17,826} \\
\hline & Сумісна оцінка & 5,424 & 14,595 & 4,747 & 26,095 \\
\hline & $\begin{array}{c}\text { Середня сумісна } \\
\text { оцінка }\end{array}$ & \multicolumn{4}{|c|}{12,715} \\
\hline
\end{tabular}


Результати статистичної обробки даних стійкості крайки до надриву

\begin{tabular}{|c|c|c|c|c|c|}
\hline & & \multicolumn{4}{|c|}{ Стійкість крайки до надриву, мН } \\
\hline & & \multicolumn{4}{|c|}{ Номінал банкноти, грн } \\
\hline & & \multicolumn{2}{|c|}{1 грн } & \multicolumn{2}{|c|}{2 грн } \\
\hline & & $\begin{array}{c}\text { Машинний } \\
\text { напрям }\end{array}$ & $\begin{array}{c}\text { Поперечний } \\
\text { напрям }\end{array}$ & $\begin{array}{c}\text { Машинний } \\
\text { напрям }\end{array}$ & $\begin{array}{c}\text { Поперечний } \\
\text { напрям }\end{array}$ \\
\hline \multirow{7}{*}{$\begin{array}{l}\bar{m} \\
\text { ơ } \\
\text { ํ. }\end{array}$} & Середнє & 9,200 & 9,000 & 9,290 & 8,810 \\
\hline & $\begin{array}{l}\text { Середньо-квадра- } \\
\text { тичне відхилення }\end{array}$ & 0,854 & 0,789 & 0,474 & 0,410 \\
\hline & $\begin{array}{c}\text { Середня похибка } \\
\text { середнього } \\
\text { арифметичного }\end{array}$ & 0,085 & 0,079 & 0,047 & 0,041 \\
\hline & Відносна похибка, \% & 0,928 & 0,877 & 0,510 & 0,465 \\
\hline & $\begin{array}{c}\text { Середня відносна } \\
\text { похибка, \% }\end{array}$ & \multicolumn{4}{|c|}{0,695} \\
\hline & Коефіцієнт варіації, \% & 9,283 & 8,767 & 5,102 & 4,654 \\
\hline & $\begin{array}{c}\text { Середній коефіцієнт } \\
\text { варіації, \% } \\
\end{array}$ & \multicolumn{4}{|c|}{6,951} \\
\hline \multirow{13}{*}{ 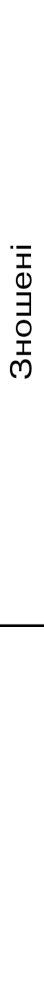 } & Мінімум & 7 & 7 & 7 & 7 \\
\hline & Максимум & 9 & 9,5 & 11 & 14,3 \\
\hline & Середнє & 8 & 8,5 & 8,5 & 8,5 \\
\hline & $\begin{array}{c}\text { Середньо-квадра- } \\
\text { тичне відхилення }\end{array}$ & 0,78 & 0,85 & 1,28 & 2,71 \\
\hline & $\begin{array}{c}\text { Середня похибка } \\
\text { середнього } \\
\text { арифметичного }\end{array}$ & 0,078 & 0,085 & 0,128 & 0,271 \\
\hline & Відносна похибка, \% & 0,975 & 1,000 & 1,506 & 3,188 \\
\hline & $\begin{array}{c}\text { Середня відносна } \\
\text { похибка, \% }\end{array}$ & \multicolumn{4}{|c|}{1,667} \\
\hline & Коефіцієнт варіації, \% & 9,750 & 10,000 & 15,059 & 31,882 \\
\hline & $\begin{array}{c}\text { Середній коефіцієнт } \\
\text { варіації, \% } \\
\end{array}$ & \multicolumn{4}{|c|}{16,673} \\
\hline & $\begin{array}{c}\text { Зміна показника в } \\
\text { результаті зношу- } \\
\text { вання, \% } \\
\end{array}$ & 13,043 & 5,556 & 8,504 & 3,519 \\
\hline & $\begin{array}{c}\text { Середня зміна } \\
\text { показника в резуль- } \\
\text { таті зношування, \% }\end{array}$ & \multicolumn{4}{|c|}{7,655} \\
\hline & Сумісна оцінка & 9,689 & 4,178 & 5,348 & 1,092 \\
\hline & $\begin{array}{c}\text { Середня сумісна } \\
\text { оцінка }\end{array}$ & \multicolumn{4}{|c|}{5,077} \\
\hline
\end{tabular}




\section{ТЕХНОЛОГІЧНІ ПРОЦЕСИ}

Таблиця 8

Результати статистичної обробки даних стійкості крайки надриву роздиранням

\begin{tabular}{|c|c|c|c|c|c|}
\hline & & \multirow{2}{*}{\multicolumn{4}{|c|}{$\begin{array}{c}\text { Стійкість крайки до надриву роздиранням, мН } \\
\text { Номінал банкноти. грн }\end{array}$}} \\
\hline & & & & & \\
\hline & & \multicolumn{2}{|c|}{$1 \mathrm{rpH}$} & \multicolumn{2}{|c|}{2 грн } \\
\hline & & $\begin{array}{c}\text { Машинний } \\
\text { напрям }\end{array}$ & $\begin{array}{c}\text { Поперечний } \\
\text { напрям }\end{array}$ & $\begin{array}{c}\text { Машинний } \\
\text { напрям } \\
\end{array}$ & $\begin{array}{c}\text { Поперечний } \\
\text { напрям }\end{array}$ \\
\hline \multirow{7}{*}{ 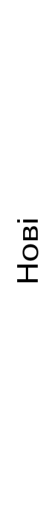 } & Середнє & 24,300 & 37,900 & 38,000 & 49,140 \\
\hline & $\begin{array}{l}\text { Середньо-квадра- } \\
\text { тичне відхилення }\end{array}$ & 2,435 & 5,515 & 3,162 & 3,532 \\
\hline & $\begin{array}{c}\text { Середня похибка } \\
\text { середнього } \\
\text { арифметичного }\end{array}$ & 0,244 & 0,552 & 0,316 & 0,353 \\
\hline & Відносна похибка, \% & 1,002 & 1,455 & 0,832 & 0,719 \\
\hline & $\begin{array}{c}\text { Середня відносна } \\
\text { похибка, \% }\end{array}$ & \multicolumn{4}{|c|}{1,002} \\
\hline & Коефіцієнт варіації, \% & 10,021 & 14,551 & 8,321 & 7,188 \\
\hline & $\begin{array}{c}\text { Середній коефіцієнт } \\
\text { варіації, \% }\end{array}$ & \multicolumn{4}{|c|}{10,020} \\
\hline \multirow{9}{*}{ 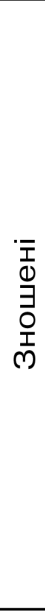 } & Мінімум & 17 & 23 & 23 & 28 \\
\hline & Максимум & 24 & 35 & 28 & 35 \\
\hline & Середнє & 20 & 28 & 25 & 31 \\
\hline & $\begin{array}{c}\text { Середньо-квадра- } \\
\text { тичне відхилення }\end{array}$ & 2,3 & 4,28 & 1,69 & 2,91 \\
\hline & $\begin{array}{c}\text { Середня похибка } \\
\text { середнього } \\
\text { арифметичного }\end{array}$ & 0,230 & 0,428 & 0,169 & 0,291 \\
\hline & Відносна похибка, \% & 1,150 & 1,529 & 0,676 & 0,939 \\
\hline & $\begin{array}{c}\text { Середня відносна } \\
\text { похибка, \% }\end{array}$ & \multicolumn{4}{|c|}{1,073} \\
\hline & Коефіцієнт варіації, \% & 11,500 & 15,286 & 6,760 & 9,387 \\
\hline & $\begin{array}{c}\text { Середній коефіцієнт } \\
\text { варіації, \% }\end{array}$ & \multicolumn{4}{|c|}{10,733} \\
\hline & $\begin{array}{c}\text { Зміна показника в } \\
\text { результаті } \\
\text { зношування, \% } \\
\end{array}$ & 17,695 & 26,121 & 34,211 & 36,915 \\
\hline & $\begin{array}{c}\text { Середня зміна } \\
\text { показника в резуль- } \\
\text { таті зношування, \% }\end{array}$ & \multicolumn{4}{|c|}{28,736} \\
\hline & Сумісна оцінка & 11,601 & 12,377 & 31,910 & 31,223 \\
\hline & $\begin{array}{c}\text { Середня сумісна } \\
\text { оцінка }\end{array}$ & \multicolumn{4}{|c|}{21,778} \\
\hline
\end{tabular}


Таблиця 9

Результати статистичної обробки даних нульової розривної довжини

\begin{tabular}{|c|c|c|c|c|c|}
\hline & & \multicolumn{4}{|c|}{ Нульова розривна довжина, м } \\
\hline & & \multicolumn{4}{|c|}{ Номінал банкноти } \\
\hline & & \multicolumn{2}{|c|}{$1 \mathrm{rpH}$} & \multicolumn{2}{|c|}{2 грн } \\
\hline & & $\begin{array}{l}\text { Машинний } \\
\text { напрям }\end{array}$ & $\begin{array}{c}\text { Поперечний } \\
\text { напрям }\end{array}$ & $\begin{array}{c}\text { Машинний } \\
\text { напрям }\end{array}$ & $\begin{array}{c}\text { Поперечни } \\
\text { й напрям }\end{array}$ \\
\hline \multirow{7}{*}{$\begin{array}{l}\overline{\bar{m}} \\
\text { of } \\
\text { ㅇ․ }\end{array}$} & Середнє & 120,900 & 91,500 & 171,100 & 111,700 \\
\hline & $\begin{array}{l}\text { Середньо-квадра- } \\
\text { тичне відхилення }\end{array}$ & 8,391 & 9,087 & 9,371 & 5,794 \\
\hline & $\begin{array}{c}\text { Середня похибка } \\
\text { середнього } \\
\text { арифметичного } \\
\end{array}$ & 0,839 & 0,909 & 0,937 & 0,579 \\
\hline & Відносна похибка, \% & 0,694 & 0,993 & 0,548 & 0,519 \\
\hline & $\begin{array}{c}\text { Середня відносна } \\
\text { похибка, \% } \\
\end{array}$ & \multicolumn{4}{|c|}{0,688} \\
\hline & $\begin{array}{c}\text { Коефіцієнт варіації, } \\
\%\end{array}$ & 6,940 & 9,931 & 5,477 & 5,187 \\
\hline & $\begin{array}{c}\text { Середній коефіцієнт } \\
\text { варіації, \% } \\
\end{array}$ & \multicolumn{4}{|c|}{6,884} \\
\hline \multirow{9}{*}{ 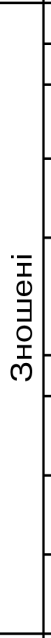 } & Мінімум & 105 & 85 & 100 & 89 \\
\hline & Максимум & 132 & 102 & 127 & 109 \\
\hline & Середнє & 118 & 93 & 116 & 97 \\
\hline & $\begin{array}{l}\text { Середньо-квадра- } \\
\text { тичне відхилення }\end{array}$ & 8,93 & 5,61 & 8,61 & 7,37 \\
\hline & $\begin{array}{c}\text { Середня похибка } \\
\text { середнього } \\
\text { арифметичного } \\
\end{array}$ & 0,893 & 0,561 & 0,861 & 0,737 \\
\hline & Відносна похибка, \% & 0,757 & 0,603 & 0,742 & 0,760 \\
\hline & $\begin{array}{c}\text { Середня відносна } \\
\text { похибка, \% }\end{array}$ & \multicolumn{4}{|c|}{0,716} \\
\hline & $\begin{array}{c}\text { Коефіцієнт варіації, } \\
\%\end{array}$ & 7,568 & 6,032 & 7,422 & 7,598 \\
\hline & $\begin{array}{c}\text { Середній коефіцієнт } \\
\text { варіації, \% } \\
\end{array}$ & \multicolumn{4}{|c|}{7,155} \\
\hline & $\begin{array}{c}\text { 3міна показника в } \\
\text { результаті } \\
\text { зношування, \% }\end{array}$ & 2,399 & $-1,639$ & 32,203 & 13,160 \\
\hline & $\begin{array}{c}\text { Середня зміна } \\
\text { показника в резуль- } \\
\text { таті зношування, \% }\end{array}$ & \multicolumn{4}{|c|}{11,531} \\
\hline & Сумісна оцінка & 2,336 & $-1,411$ & 34,911 & 14,305 \\
\hline & $\begin{array}{c}\text { Середня сумісна } \\
\text { оцінка }\end{array}$ & \multicolumn{4}{|c|}{12,535} \\
\hline
\end{tabular}




\section{ТЕХНОЛОГІЧНІ ПРОЦЕСИ}

Таблиця 10

Результати статистичної обробки даних зміни банкнотами жорсткості за Табером

\begin{tabular}{|c|c|c|c|c|c|}
\hline & & \multicolumn{4}{|c|}{ Жорсткість за Табером, мH$^{\star}$ м } \\
\hline & & \multicolumn{4}{|c|}{ Номінал банкноти, грн } \\
\hline & & \multicolumn{2}{|c|}{1 грн } & \multicolumn{2}{|c|}{2 грн } \\
\hline & & $\begin{array}{c}\text { Машинний } \\
\text { напрям }\end{array}$ & $\begin{array}{c}\text { Поперечний } \\
\text { напрям }\end{array}$ & $\begin{array}{c}\text { Машинний } \\
\text { напрям }\end{array}$ & $\begin{array}{c}\text { Поперечний } \\
\text { напрям }\end{array}$ \\
\hline \multirow{7}{*}{ 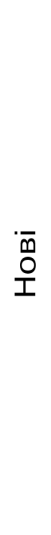 } & Середнє & 3,4 & 1,5 & 1,620 & 0,720 \\
\hline & $\begin{array}{c}\text { Середньо-квадра- } \\
\text { тичне відхилення }\end{array}$ & 0,233 & 0,176 & 0,271 & 0,420 \\
\hline & $\begin{array}{c}\text { Середня похибка } \\
\text { середнього } \\
\text { арифметичного } \\
\end{array}$ & 0,023 & 0,018 & 0,027 & 0,042 \\
\hline & Відносна похибка, \% & 0,685 & 1,173 & 1,673 & 5,833 \\
\hline & $\begin{array}{c}\text { Середня відносна } \\
\text { похибка, \% }\end{array}$ & \multicolumn{4}{|c|}{2,341} \\
\hline & Коефіцієнт варіації, \% & 6,853 & 11,733 & 16,728 & 58,333 \\
\hline & $\begin{array}{c}\text { Середній коефіцієнт } \\
\text { варіації, \% } \\
\end{array}$ & \multicolumn{4}{|c|}{23,412} \\
\hline \multirow{9}{*}{$\begin{array}{l}\bar{T} \\
\overline{1} \\
\stackrel{\exists}{\exists} \\
0 \\
\frac{0}{1} \\
m\end{array}$} & Мінімум & 0,45 & 0,2 & 0,4 & 0,2 \\
\hline & Максимум & 0,65 & 0,7 & 0,75 & 0,55 \\
\hline & Середнє & 0,56 & 0,36 & 0,55 & 0,32 \\
\hline & $\begin{array}{l}\text { Середньо-квадра- } \\
\text { тичне відхилення }\end{array}$ & 0,091 & 0,139 & 0,135 & 0,101 \\
\hline & $\begin{array}{c}\text { Середня похибка } \\
\text { середнього } \\
\text { арифметичного } \\
\end{array}$ & 0,009 & 0,014 & 0,014 & 0,010 \\
\hline & Відносна похибка, \% & 1,625 & 3,861 & 2,455 & 3,156 \\
\hline & $\begin{array}{c}\text { Середня відносна } \\
\text { похибка, \% } \\
\end{array}$ & \multicolumn{4}{|c|}{2,774} \\
\hline & Коефіцієнт варіації, \% & 16,250 & 38,611 & 24,545 & 31,563 \\
\hline & $\begin{array}{c}\text { Середній коефіцієнт } \\
\text { варіації, \% } \\
\end{array}$ & \multicolumn{4}{|c|}{27,742} \\
\hline & $\begin{array}{c}\text { Зміна показника в } \\
\text { результаті } \\
\text { зношування, \% }\end{array}$ & 83,529 & 76,000 & 66,049 & 55,556 \\
\hline & $\begin{array}{c}\text { Середня зміна } \\
\text { показника в резуль- } \\
\text { таті зношування, \% }\end{array}$ & \multicolumn{4}{|c|}{70,284} \\
\hline & Сумісна оцінка & 47,363 & 18,833 & 22,236 & 8,376 \\
\hline & $\begin{array}{c}\text { Середня сумісна } \\
\text { оцінка }\end{array}$ & \multicolumn{4}{|c|}{24,202} \\
\hline
\end{tabular}


Таблиця 11

Результати статистичної обробки даних жорсткості методом резонансу та кільця

\begin{tabular}{|c|c|c|c|c|c|}
\hline & & $\begin{array}{r}\text { Жорсткість } \\
\text { Поперечн }\end{array}$ & $\begin{array}{l}\text { езонанс) } \\
\text { напрям }\end{array}$ & $\begin{array}{l}\text { Жорстк } \\
\text { Машин }\end{array}$ & $\begin{array}{l}\text { (кільце) } \\
\text { напрям }\end{array}$ \\
\hline & & \multicolumn{4}{|c|}{ Номінал банкноти, грн } \\
\hline \multirow{7}{*}{$\begin{array}{l}\overline{\mathrm{m}} \\
\text { 운 }\end{array}$} & Середнє & 33,000 & 28,890 & 77,800 & 64,750 \\
\hline & $\begin{array}{l}\text { Середньо-квадра- } \\
\text { тичне відхилення }\end{array}$ & 1,640 & 0,579 & 10,100 & 15,050 \\
\hline & $\begin{array}{c}\text { Середня похибка } \\
\text { середнього } \\
\text { арифметичного }\end{array}$ & 0,164 & 0,058 & 1,010 & 1,505 \\
\hline & Відносна похибка, \% & 0,497 & 0,200 & 1,298 & 2,324 \\
\hline & $\begin{array}{c}\text { Середня відносна } \\
\text { похибка, \% }\end{array}$ & \multicolumn{2}{|c|}{0,349} & \multicolumn{2}{|c|}{1,811} \\
\hline & $\begin{array}{c}\text { Коефіцієнт варіації, } \\
\%\end{array}$ & 4,970 & 2,004 & 12,982 & 23,243 \\
\hline & $\begin{array}{c}\text { Середній коефіцієнт } \\
\text { варіації, \% }\end{array}$ & \multicolumn{2}{|c|}{3,487} & \multicolumn{2}{|c|}{18,113} \\
\hline \multirow{13}{*}{ 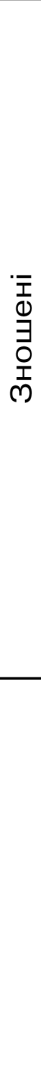 } & Мінімум & 24,800 & 26,200 & 15,000 & 25,000 \\
\hline & Максимум & 28,700 & 30,700 & 34,000 & 37,000 \\
\hline & Середнє & 26,138 & 28,250 & 26,250 & 31,125 \\
\hline & $\begin{array}{c}\text { Середньо- } \\
\text { квадратичне } \\
\text { відхилення }\end{array}$ & 1,300 & 1,700 & 5,950 & 4,050 \\
\hline & $\begin{array}{c}\text { Середня похибка } \\
\text { середнього } \\
\text { арифметичного }\end{array}$ & 0,130 & 0,170 & 0,595 & 0,405 \\
\hline & Відносна похибка, \% & 0,497 & 0,602 & 2,267 & 1,301 \\
\hline & $\begin{array}{c}\text { Середня відносна } \\
\text { похибка, \% } \\
\end{array}$ & \multicolumn{2}{|c|}{0,550} & \multicolumn{2}{|c|}{1,784} \\
\hline & $\begin{array}{c}\text { Коефіцієнт варіації, } \\
\%\end{array}$ & 4,974 & 6,018 & 22,667 & 13,012 \\
\hline & $\begin{array}{c}\text { Середній коефіцієнт } \\
\text { варіації, \% }\end{array}$ & \multicolumn{2}{|c|}{5,496} & \multicolumn{2}{|c|}{17,839} \\
\hline & $\begin{array}{c}\text { Зміна показника в } \\
\text { результаті } \\
\text { зношування, \% }\end{array}$ & 20,794 & 2,215 & 66,260 & 51,931 \\
\hline & $\begin{array}{c}\text { Середня зміна } \\
\text { показника в } \\
\text { результаті } \\
\text { зношування, \% }\end{array}$ & \multicolumn{2}{|c|}{23,009} & \multicolumn{2}{|c|}{59,095} \\
\hline & Сумісна оцінка & 29,575 & 3,493 & 25,366 & 19,495 \\
\hline & $\begin{array}{c}\text { Середня сумісна } \\
\text { оцінка }\end{array}$ & \multicolumn{2}{|c|}{33,067} & \multicolumn{2}{|c|}{22,431} \\
\hline
\end{tabular}




\section{ТЕХНОЛОГІЧН ПРОЦЕСИ}

Таблиця 12

Результати статистичної обробки даних зміни маси банкнот (г)

\begin{tabular}{|c|c|c|c|}
\hline & \multirow[b]{3}{*}{ Середнє } & \multicolumn{2}{|c|}{ Maca, $г$} \\
\hline & & \multicolumn{2}{|c|}{ Номінал банкноти, грн } \\
\hline \multirow{7}{*}{ 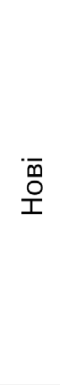 } & & 0,659 & 0,656 \\
\hline & Середньоквадратичне відхилення & 0,016 & 0,018 \\
\hline & $\begin{array}{c}\text { Середня похибка середнього } \\
\text { арифметичного }\end{array}$ & 0,002 & 0,002 \\
\hline & Відносна похибка, \% & 0,243 & 0,274 \\
\hline & Середня відносна похибка, \% & \multicolumn{2}{|c|}{0,259} \\
\hline & Коефіцієнт варіації, \% & 2,428 & 2,744 \\
\hline & Середній коефіцієнт варіації, \% & \multicolumn{2}{|c|}{2,586} \\
\hline \multirow{9}{*}{ 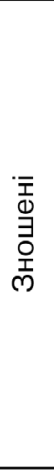 } & Мінімум & 0,585 & 0,645 \\
\hline & Максимум & 0,772 & 0,767 \\
\hline & Середне & 0,696 & 0,702 \\
\hline & Середньоквадратичне відхилення & 0,032 & 0,024 \\
\hline & $\begin{array}{c}\text { Середня похибка середнього } \\
\text { арифметичного }\end{array}$ & 0,003 & 0,002 \\
\hline & Відносна похибка, \% & 0,460 & 0,342 \\
\hline & Середня відносна похибка, \% & \multicolumn{2}{|c|}{0,401} \\
\hline & Коефіцієнт варіації, \% & 4,598 & 3,419 \\
\hline & Середній коефіцієнт варіації, \% & \multicolumn{2}{|c|}{4,008} \\
\hline & $\begin{array}{c}\text { Зміна показника в результаті } \\
\text { зношування, \% }\end{array}$ & 5,615 & 7,012 \\
\hline & $\begin{array}{c}\text { Середня зміна показника в результаті } \\
\text { зношування, \% }\end{array}$ & \multicolumn{2}{|c|}{3,157} \\
\hline & Сумісна оцінка & 10,799 & 15,996 \\
\hline & Середня сумісна оцінка & \multicolumn{2}{|c|}{13,397} \\
\hline
\end{tabular}

Таблиця 13

Сумісна оцінка точності показників зношування

\begin{tabular}{|c|c|c|c|c|c|}
\hline & \multirow{2}{*}{$\begin{array}{c}\text { Середня } \\
\text { зміна } \\
\text { показ- } \\
\text { ника в } \\
\text { результаті } \\
\text { зношу- } \\
\text { вання, \% }\end{array}$} & \multirow{2}{*}{$\begin{array}{c}\text { Середня } \\
\text { відносна } \\
\text { похибка } \\
\text { для } \\
\text { нових } \\
\text { банкнот, } \\
\%\end{array}$} & \multirow{2}{*}{$\begin{array}{c}\text { Середня } \\
\text { відносна } \\
\text { похибка для } \\
\text { зношених } \\
\text { банкнот, \% }\end{array}$} & \multicolumn{2}{|c|}{ Сумісна оцінка } \\
\hline & & & & $\begin{array}{c}\text { Числове } \\
\text { значен- } \\
\text { ня, \% }\end{array}$ & $\begin{array}{l}\text { Рей- } \\
\text { тинг }\end{array}$ \\
\hline $\begin{array}{c}\text { Зміна яскравості } \\
\text { банкнот } \\
\end{array}$ & 24,828 & 0,110 & 1,275 & 19,740 & 7 \\
\hline $\begin{array}{c}\text { Повітропроник- } \\
\text { ність } \\
\end{array}$ & 78,832 & 0,864 & 4,878 & 16,658 & 9 \\
\hline Шорсткість & 633,178 & 0,446 & 1,834 & 317,683 & 1 \\
\hline
\end{tabular}


Закінчення табл. 13

\begin{tabular}{|c|c|c|c|c|c|}
\hline & \multirow{2}{*}{$\begin{array}{c}\text { Середня } \\
\text { зміна } \\
\text { показ- } \\
\text { ника в } \\
\text { результаті } \\
\text { зношу- } \\
\text { вання, \% }\end{array}$} & \multirow{2}{*}{$\begin{array}{c}\text { Середня } \\
\text { відносна } \\
\text { похибка } \\
\text { для } \\
\text { нових } \\
\text { банкнот, } \\
\%\end{array}$} & \multirow{2}{*}{$\begin{array}{c}\text { Середня } \\
\text { відносна } \\
\text { похибка для } \\
\text { зношених } \\
\text { банкнот, \% }\end{array}$} & \multicolumn{2}{|c|}{ Сумісна оцінка } \\
\hline & & & & $\begin{array}{c}\text { Числове } \\
\text { значен- } \\
\text { ня, \% }\end{array}$ & $\begin{array}{l}\text { Рей- } \\
\text { тинг }\end{array}$ \\
\hline $\begin{array}{c}\text { Кількість подвійних } \\
\text { перегинів }\end{array}$ & 74,084 & 2,373 & 1,275 & 18,116 & 8 \\
\hline Руйнівне зусилля & 36,693 & 0,558 & 1,718 & 21,462 & 6 \\
\hline $\begin{array}{c}\text { Відносне } \\
\text { подовження }\end{array}$ & 17,826 & 1,048 & 1,481 & 12,715 & 11 \\
\hline $\begin{array}{c}\text { Стійкість крайки до } \\
\text { надриву }\end{array}$ & 28,736 & 0,695 & 1,667 & 5,077 & 13 \\
\hline $\begin{array}{c}\text { Стійкість крайки до } \\
\text { надриву } \\
\text { роздиранням }\end{array}$ & 28,736 & 1,002 & 1,073 & 21,778 & 5 \\
\hline $\begin{array}{c}\text { Нульова розривна } \\
\text { довжина }\end{array}$ & 11,531 & 0,688 & 0,716 & 12,535 & 12 \\
\hline $\begin{array}{c}\text { Жорсткість за } \\
\text { Табером }\end{array}$ & 70,284 & 2,341 & 2,774 & 24,202 & 3 \\
\hline $\begin{array}{l}\text { Жорсткість (за } \\
\text { методом } \\
\text { резонансу) } \\
\end{array}$ & 23,009 & 0,349 & 0,550 & 33,067 & 2 \\
\hline $\begin{array}{l}\text { Жорсткість (за } \\
\text { методом кільця) }\end{array}$ & 59,095 & 1,784 & 1,784 & 22,431 & 4 \\
\hline Маса банкноти & 3,157 & 0,259 & 0,401 & 13,397 & 10 \\
\hline
\end{tabular}

\section{Висновки}

Розраховано обсяг вибіркової сукупності банкнот, що перебували в реальному обігу, на основі яких було здійснене оцінювання ступеня зношуваності. Обсяг вибіркової сукупності склав 1010 банкнот кожного 3 досліджуваних номіналів (1 грн та 2 грн) (довірча ймовірність 95,4 \% і похибка - 3 \%).

В дослідженнях встановлено зміни в результаті зношування таких показників: яскравість, повітропроникність, шорсткість (за Бендстеном), опір зламу (кількість подвійних перегинів), руйнівне зусилля, показник відносного подовження, стійкість крайки до надриву, стійкість крайки до надриву роздиранням, нульова розривна довжина, жорсткість за Табером, жорсткість за методом резонансу, жорсткість за методом кільця, зміна маси банкнот. За всіма показниками зношування банкноти номіналом 2 грн мають кращу стійкість до зношування, що може бути пояснено наявністю інтагліодруку в технологічному процесі виготовлення 2 грн і відсутністю його під час виготовлення 1 грн. Під час 
інтагліодруку банкноти піддаються тисненню із надзвичайно великими зусиллями, що ущільнює структуру паперової основи та впливає на зношуваність банкнот.

Запропоновано встановити рейтинг показників зношування з точки зору точності (від найкращого до найгіршого) 3 урахуванням сумісної оцінки, що враховує зміну показника в результаті зношування $\Delta \mathrm{X}$, відносну похибку для нових $\delta_{\text {new }}$ та відносну похибку для зношених банкнот $\delta_{\text {det. }}$ Важливо, що відносна похибка враховує як середнє квадратичне відхилення (показник розсіювання результатів спостережень відносно математичного сподівання), так і число спостережень. Рейтинг за сумісною оцінкою $€$ таким: шорсткість (за Бендстеном), жорсткість за методом резонансу, жорсткість за методом кільця, жорсткість за Табером, стійкість крайки до надриву роздиранням, руйнівне зусилля, зміна яскравості, опір зламу (кількість подвійних перегинів), повітропроникність, зміна маси банкнот, показник відносного подовження, нульова розривна довжина, стійкість крайки до надриву.

1. Киричок Т. Ю. Класифікація пошкоджень банкнот в обігу / Т. Ю. Киричок // Зб. наук. праць : Технологія і техніка друкарства. - К., 2011. № 4(34). - С. 11-20. 2. Інструкція про ведення касових операцій банками в Україні (Затверджено Постановою Правління Національного банку України від 01.06.2011 № 174). 3. Tom Buitelaar. The Colour of Soil. - DNB Cash Seminar 2008 / Amsterdam, 28-29 February, 2008. - De Nederlandsche Bank NV. - Шлях доступу : http://www.dnb.nl/binaries. 4. New Soiling Test Method : Anti-Dirty Fingers. - Peter Balke, Cash Policy Department, De Nederlandsche Bank NV. - Шлях доступу : http://www.dnb.nl/binaries. 5. W. J. Bartz and T. T. Crane. Circulation simulator method for evaluating bank note and optical feature durability // Proc. SPIE, Optical Security and Counterfeit Deterrence Techniques. - San Jose, CA, USA. - 2006. - January. - Vol. 6075. P. 607505. 6. Torsten Meuer, Jerome Martin. The Eurosystem's efforts in the search for a longer lasting banknote // Billetaria. International Review on Cash Management. - 2011. - April. - Issue 9. - P. 22-24. 7. Jan-Mark Geusebroek, Peter Markus, Peter Balke. Learning banknote Fitness for Sorting. - DNB Betalingsverkeer. Cash Policy Department, De Nederlandsche Bank NV. - Шлях доступу : http://www.dnb.nl/binaries. 8. Лист Національного банку України № 11-117/2963 від 31.07.2012. 9. Masahiro Takagi. Toshiba's banknote processing machines // Billetaria. International Review on Cash Management. - 2008. - October. - Issue 4. - P. 24-25. 10. Francisco Cantero. Banknote authentication devices // Billetaria. International Review on Cash Management. - 2010. - October. - Issue 8. - P. 21. 11. TAPPI T 452 om-98. Brightness of pulp, paper, and paperboard (directional reflectance at 457 nm). 12. ДСТУ ISO 13655:2006. Поліграфія. Спектральні вимірювання та розрахунок колориметричних характеристик поліграфічно відтворених зображень (ISO 13655:1996, IDT). 13. ДСТУ 2037-92 (ГОСТ 30022. 1-93) (ISO 5636-3:1984). Бумага и картон. Метод определения воздухопроница- 
емости (средний диапазон измерений). Метод Бендстена. 14. ДСту 2047-92 (ГОСТ 300 22. 2-93) (ISO 8791-2:1990). Бумага и картон. Метод определения шероховатости (метод с применением пропускания воздуха). Метод Бендстена. 15. ДСТУ 3476-96 (ГОСТ ИСО 5625-97) (ISO 5625:1993). Папір. Визначення міцності на злом під час багаторазових перегинів. 16. ДСТУ 3643-97 (ГОСТ 10711-97). Папір та картон. Метод визначення руйнівного зусилля під час стиснення кільця (RCT). 17. TAPPI T 403 om-10. Bursting Strength of Paper. 18. ДСТУ 3370-96 (ГОСТ 30436-96) (ISO 1924-2:1985). Папір та картон. Визначення міцності під час розтягування. Частина 2. Метод розтягування з постійною швидкістю. 19. TAPPI T 470 om-89. Edge Tearing Resistance of Paper (edge-tear stirrup method). 20. ДСТY ISO 15361:2008. Напівфабрикати волокнисті. Метод визначення міцності на розрив за нульової затискної довжини в сухому чи вологому стані (ISO 15361:2000, IDT). 21. TAPPI T $231 \mathrm{~cm}-07$. Zero-Span Breaking Strength of Pulp (Dry Zero Span Tensile). 22. ДСТУ 3369-96 (ГОСТ 9582-96) (ISO 2493:1992) Папір та картон. Метод визначення опору згинанню. 23. ДСТУ 2907-96 (ГОСТ 30271-96) (ISO 5629:1983) Папір та картон. Визначення жорсткості під час згинання. Метод резонансу. 24. ДСту ISO 12192:2008. Папір і картон. Визначення міцності методом стиснення кільця (ISO 12192:2002, IDT). 25. ДСТУ 3371-96 (ГОСТ 30435-96) (ISO 5628:1990) Папір та картон. Визначення жорсткості під час згинання статичними методами. Загальні положення.

1. Kyrychok T. lu. Klasyfikatsiia poshkodzhen banknot v obihu / T. lu. Kyrychok // Zb. nauk. prats : Tekhnolohiia i tekhnika drukarstva. - K., 2011. — № 4(34). S. 11-20. 2. Instruktsiia pro vedennia kasovykh operatsii bankamy v Ukraini (Zatverdzheno Postanovoiu Pravlinnia Natsionalnoho banku Ukrainy vid 01.06.2011 № 174). 3. Tom Buitelaar. The Colour of Soil. - DNB Cash Seminar 2008 / Amsterdam, 28-29 February, 2008. - De Nederlandsche Bank NV. Shliakh dostupu : http://www.dnb.nl/binaries. 4. New Soiling Test Method : AntiDirty Fingers. - Peter Balke, Cash Policy Department, De Nederlandsche Bank NV. - Shliakh dostupu : http://www.dnb.nl/binaries. 5. W. J. Bartz and T. T. Crane. Circulation simulator method for evaluating bank note and optical feature durability // Proc. SPIE, Optical Security and Counterfeit Deterrence Techniques. San Jose, CA, USA. - 2006. - January. - Vol. 6075. - R. 607505. 6. Torsten Meuer, Jerome Martin. The Eurosystem's efforts in the search for a longer lasting banknote // Billetaria. International Review on Cash Management. - 2011. April. - Issue 9. - P. 22-24. 7. Jan-Mark Geusebroek, Peter Markus, Peter Balke. Learning banknote Fitness for Sorting. - DNB Betalingsverkeer. Cash Policy Department, De Nederlandsche Bank NV. - Shliakh dostupu : http://www.dnb.nl/binaries. 8. Lyst Natsionalnoho banku Ukrainy № 11-117/2963 vid 31.07.2012. 9. Masahiro Takagi. Toshiba's banknote processing machines // Billetaria. International Review on Cash Management. 2008. - October. - Issue 4. - P. 24-25. 10. Francisco Cantero. Banknote authentication devices // Billetaria. International Review on Cash Management. - 2010. - October. - Issue 8. - P. 21. 11. TAPPI T 452 om-98. Brightness of pulp, paper, and paperboard (directional reflectance at $457 \mathrm{~nm}$ ). 12. DSTU ISO 13655:2006. Polihrafiia. Spektralni vymiriuvannia ta rozrakhunok kolorymetrychnykh kharakterystyk polihrafichno vidtvorenykh zobrazhen 
(ISO 13655:1996, IDT). 13. DSTU 2037-92 (GOST 300 22. 1-93) (ISO 5636-3:1984). Bumaga i karton. Metod opredelenija vozduhopronicaemosti (srednij diapazon izmerenij). Metod Bendstena. 14. DSTU 2047-92 (GOST 300 22. 2-93) (ISO 8791-2:1990). Bumaga i karton. Metod opredelenija sherohovatosti (metod s primeneniem propuskanija vozduha). Metod Bendstena. 15. DSTU 3476-96 (GOST ISO 5625-97) (ISO 5625:1993). Papir. Vyznachennia mitsnosti na zlom pid chas bahatorazovykh perehyniv. 16. DSTU 3643-97 (GOST 10711-97). Papir ta karton. Metod vyznachennia ruinivnoho zusyllia pid chas stysnennia kiltsia (RCT). 17. TAPPI T 403 om-10. Bursting Strength of Paper. 18. DSTU 3370-96 (GOST 30436-96) (ISO 1924-2:1985). Papir ta karton. Vyznachennia mitsnosti pid chas roztiahuvannia. Chastyna 2. Metod roztiahuvannia z postiinoiu shvydkistiu. 19. TAPPI T 470 om-89. Edge Tearing Resistance of Paper (edge-tear stirrup method). 20. DSTU ISO 15361:2008. Napivfabrykaty voloknysti. Metod vyznachennia mitsnosti na rozryv za nulovoi zatysknoi dovzhyny v sukhomu chy volohomu stani (ISO 15361:2000, IDT). 21. TAPPI T 231 $\mathrm{cm}-07$. Zero-Span Breaking Strength of Pulp (Dry Zero Span Tensile). 22. DSTU 3369-96 (GOST 9582-96) (ISO 2493:1992) Papir ta karton. Metod vyznachennia oporu zghynanniu. 23. DSTU 2907-96 (GOST 30271-96) (ISO 5629:1983) Papir ta karton. Vyznachennia zhorstkosti pid chas zghynannia. Metod rezonansu. 24. DSTU ISO 12192:2008. Papir i karton. Vyznachennia mitsnosti metodom stysnennia kiltsia (ISO 12192:2002, IDT). 25. DSTU 3371-96 (GOST 30435-96) (ISO 5628:1990) Papir ta karton. Vyznachennia zhorstkosti pid chas zghynannia statychnymy metodamy. Zahalni polozhennia.

Рецензент - А. В. Шевчук, д.т.н., професор, перший заступник генерального директора БМД НБУ, директор Банкнотной фабрики

Надійшла до редакції 25.09.12 